Afr. J. Trad. CAM (2006) 3 (4): 59 - 65

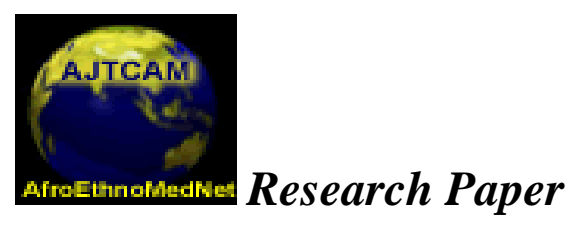
Afr. J. Traditional, Complementary and Alternative Medicines www.africanethnomedicines.net

\title{
ISSN 0189-6016@2006
}

\section{ISOLATION OF TWO FLAVONOIDS FROM BAUHINIA MONANDRA (KURZ) LEAVES AND THEIR ANTIOXIDATIVE EFFECTS}

\author{
M. A. Aderogba*1,2 ${ }^{1, A . O . ~ O g u n d a i n i ~}{ }^{3}$ and J.N. Eloff ${ }^{2}$ \\ ${ }^{1}$ Department of Chemistry, Obafemi Awolowo University, Ile-Ife, Nigeria., \\ ${ }^{2}$ Phytomedicine Programme, Department of Paraclinical Sciences, University of Pretoria, \\ Onderstepoort 0110, South Africa, ${ }^{3}$ Department of Pharmaceutical Chemistry, Obafemi \\ Awolowo University, Ile-Ife, Nigeria. \\ * Corresponding author. Fax: +2712 529 8525, Phone +2776 4279992
}

Current address: Department of Paraclinical sciences, Phytomedicine Programme, University of Pretoria, Private bag X04, Onderstepoort, 0110, South Africa.

E-mail: marogba@yahoo.co.uk

\begin{abstract}
Bauhinia monandra (Kurz), traditionally use in the treatment of diabetes with established significant anti-diabetic activity was investigated for its antioxidant constituents since the activity demonstrated can be linked to the presence of antioxidant compounds. Bioassay directed fractionation of the ethyl acetate soluble leaves extract has led to isolation of two active compounds identified as: Quercetin-3-O-rutinoside (1) and Quercetin (2). The molecular structures elucidations of both compounds were carried out using spectroscopic studies ( ${ }^{1} \mathrm{H}$ NMR, ${ }^{13} \mathrm{C}$ NMR and MS). These compounds are reported from this species for the first time. A DPPH spectrophotometric assay was used to evaluate the antioxidant potential of the compounds. Compound $\mathbf{2}$ had higher antioxidant activity while Compound $\mathbf{1}$ had lower activity than L-ascorbic acid which was used as standard.
\end{abstract}

Key words: Bauhinia monandra; antioxidant activity; flavonoid; DPPH.

\section{Introduction}

Flavonoids constitute a major group of phenolic compounds in plants. They provide pigmentation for fruits, flowers and seeds to attract pollinators and seeds dispersers. They assist in plant defense against pathogenic microorganism (Schijlen et al., 2004, Parr and Bowell, 2000). The number of flavonoids is constantly increasing due to the structural variation associated with these compounds. It is well known that 
Afr. J. Trad. CAM (2006) 3 (4): 59 - 65

antioxidant activity in higher plants has often been associated with phenolic compounds (Thabrew et al., 1998).

Bauhinia monandra (Kurz) belongs to the family Fabaceae. It is traditionally used for the treatment of diabetes and as a diuretic (Argolo et al., 2004). Freshly crushed leaves are also used to treat stonefish stings (Hansworth, 1990). Pharmacological reports have shown that the ethanol extract of the leaves exhibited hypoglycaemic activity (Coelho and Silva 2000). Subsequent fractionation of the ethanol extract led to isolation of one of the active compounds which was identified as galactose-specific lectin. (Coelho and Silva, 2000). Oral administration of the stem bark extract in rats $(1 \mathrm{~g} / \mathrm{kg})$, exhibited significant anti-diabetic activity (Abo and Jimoh, 2004). Methanol leaf extracts had no antimicrobial activity against B. substilis, E. coli, S. aureus and $P$. aeruginosa (Binutu, 1986).

Many plant constituents are effective as remedy for some diseases and accounts for large number of pharmaceutical important compounds in Western Pharmacopoeia and a number of important drugs. For example, taxol and artermisinin were reported from plants (Tshibangu et al., 2002). In our quest to finding a novel antioxidant agents from plants, we have carried out bioactivity directed phytochemical study on the leaves extract of B. monandra to isolate and identify the antioxidant constituents because anti-diabetic activity has been linked to antioxidant compounds (McCune and Johns, 2002). Antioxidant potential of the isolated compounds was also evaluated using a DPPH free radical scavenging assay.

\section{Material and Methods General}

Spectroscopic data were obtained from the following instruments: UV- Versamax ${ }^{\circledR}$ microplate reader, NMR - Varian $\left({ }^{1} \mathrm{H} 300 \mathrm{MHz},{ }^{13} \mathrm{C} 75 \mathrm{MHz}\right)$, Electron impact mass spectra (EI-MS) - Shimadzu 2010 gcms. L-ascorbic acid (Merck), DPPH 2, 2-diphenyl-1-picryl hydrazyl (Sigma) and absolute methanol (Fluka).

All other chemicals used were of analytical grade obtained from BDH Chemicals Ltd, Poole England and Sigma chemical Co. USA.

\section{Plant material}

Leaves of B. monandra were collected at the Obafemi Awolowo University, IleIfe, Nigeria, in February 2005. Collected leaves were air dried at room temperature for three weeks. Dr. H.C. Illoh of the Department of Botany, Obafemi Awolowo University, Ile-Ife, authenticated the plant. A voucher specimen was deposited at the Herbarium of the Faculty of Pharmacy, Obafemi Awolowo University with herbarium number FPI 107. 
Afr. J. Trad. CAM (2006) 3 (4): 59 - 65

\section{Extraction}

Finely ground leaves $(700 \mathrm{~g})$ were extracted with methanol $(\mathrm{MeOH})$. The extract was concentrated to dryness in vacuo at $40{ }^{\circ} \mathrm{C}$ to remove the methanol. The aqueous extract was made and successively partitioned with hexane (Hex.), dichloromethane (DCM), ethyl acetate (EtOAc) and butanol $(\mathrm{BuOH})$. The combined organic layer of each partition was evaporated to dryness in vacuo at $40{ }^{\circ} \mathrm{C}$ using rotary evaporator to afford Hex., DCM, EtOAc and BuOH fractions, Table 1.

\section{Isolation of the compounds}

The EtOAc fraction $(5.40 \mathrm{~g})$ was fractionated on silica gel column chromatography using an increasing gradient of EtOAc in chloroform $\left(\mathrm{CHCl}_{3}\right)$ up to $100 \%$, followed by an increasing gradient of $\mathrm{MeOH}$ up to $100 \%$. This gave five pooled fractions $A_{1}-E_{1}$. Purification of $E_{1}(40.0 \mathrm{mg})$ on Sephadex column chromatography starting with $\mathrm{DCM}-\mathrm{MeOH}$ (7.5:2.5) followed by increasing gradient of $\mathrm{MeOH}$ up to $70 \%$ afforded compound $\mathbf{1}(19.0 \mathrm{mg})$. Combination of fractions $\mathrm{B}_{1}$ and $\mathrm{C}_{1}(330.0 \mathrm{mg})$ and subsequent fractionation on Sephadex LH-20 using toluene (Tol.) - MeOH (4:1) gave compound 2 (92.0 $\mathrm{mg})$.

Fractionation of $\mathrm{BuOH}$ fraction $(8.00 \mathrm{~g})$ on Sephadex LH-20 column starting with Tol.-EtOH (1: 1) followed by increasing gradient of EtOH up to $100 \%$ also afforded compound 1 ( $240.0 \mathrm{mg}$ ).

\section{Structure Elucidation}

Quercetin-3-O-rutinoside (1). ${ }^{13} \mathrm{C}-\mathrm{NMR}\left(75 \mathrm{MHz}\right.$, DMSO- $\left.\mathrm{d}_{6}\right) .156 .4$ (C2), 133.3 (C3), 177.4 (C4), 161.2 (C5), 98.7 (C6), 164.2 (C7), 93.6 (C8), 156.6 (C9), 103.9 (C10), $121.2\left(\mathrm{C} 1^{`}\right), 115.2\left(\mathrm{C}^{`}\right), 144.8\left(\mathrm{C}^{`}\right), 148.4\left(\mathrm{C}^{\prime}\right), 116.3$ (C5'), $121.6\left(\mathrm{C} 6^{\prime}\right), 101.2$

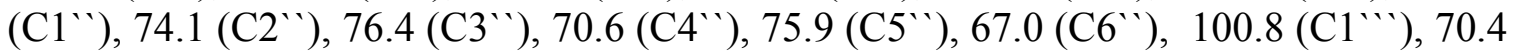
(C2 $\left.{ }^{\prime \prime}\right), 70.0\left(\mathrm{C} 3^{\prime \prime}\right), 71.8\left(\mathrm{C}^{\prime \prime}\right), 68.3\left(\mathrm{C}^{\prime \prime}\right), 17.8\left(\mathrm{C}^{\prime \prime}\right)$.

${ }^{1} \mathrm{H}$ NMR (300 MHz, DMSO-d $\mathrm{d}_{6}$ ): $\delta 3.03-3.71$ (m, rhamnoglucosyl (rutinosyl) $\mathrm{Hs}\}, 4.37(1 \mathrm{H}, \mathrm{s}$, rhamnosyl, H-1" $), 5.34\left(1 \mathrm{H}, \mathrm{d}, \mathrm{J}=6.9 \mathrm{~Hz}\right.$, glucosyl, $\left.\mathrm{H}-1^{\prime}{ }^{\prime \prime}\right), 6.18$ $(1 \mathrm{H}, \mathrm{d}, \mathrm{J}=1.2 \mathrm{~Hz}, \mathrm{H}-6), 6.37(1 \mathrm{H}, \mathrm{bs}, \mathrm{H}-8), 6.84\left(1 \mathrm{H}, \mathrm{d}, \mathrm{J}=8.1 \mathrm{~Hz}, \mathrm{H}-5^{\prime}\right), 7.54(2 \mathrm{H}, \mathrm{d}$, H-2' and $\left.\mathrm{H}^{-} 6^{\prime}\right), 12.59(1 \mathrm{H}, \mathrm{s}, 5-\mathrm{OH})$. EI-MS: $\mathrm{m} / \mathrm{z} 302\left\{[\mathrm{MH}-\text { rutinosyl }]^{+}, 100 \%\right\}$, due to loss of sugar (Markham 1982). The spectra data were in agreement with that of quercetin3-O-rutinoside reported in the literature (Harborne and Mabry, 1982; Markham 1982).

Quercetin (2). ${ }^{13} \mathrm{C}-\mathrm{NMR}$ (75 MHz, DMSO- $\mathrm{d}_{6}$ ). 146.8 (C2), 135.8 (C3), 175.9 (C4), 160.7 (C5), 98.2 (C6), 163.9 (C7), 93.4 (C8), 156.2 (C9), 103.0 (C10), 122.0 (C1'), 115.1 (C2'), $145.1\left(\mathrm{C}^{`}\right), 147.7\left(\mathrm{C}^{`}\right), 115.6\left(\mathrm{C}^{`}\right), 120.0\left(\mathrm{C}^{\prime}\right)$.

${ }^{1} \mathrm{H}$ NMR $(300 \mathrm{MHz}$, DMSO-d 6 ): $6.18(1 \mathrm{H}, \mathrm{d}, \mathrm{J}=1.8 \mathrm{~Hz}, \mathrm{H}-6), 6.40(1 \mathrm{H}, \mathrm{d}, \mathrm{J}=2.1$ $\mathrm{Hz}, \mathrm{H}-8), 6.89\left(1 \mathrm{H}, \mathrm{d}, \mathrm{J}=8.4 \mathrm{~Hz}, \mathrm{H}-5^{\prime}\right), 7.54\left(1 \mathrm{H}, \mathrm{dd}, \mathrm{J}=2.1\right.$ and $\left.8.7 \mathrm{~Hz}, \mathrm{H}-6^{\prime}\right), 7.67$ $\left(1 \mathrm{H}, \mathrm{d}, \mathrm{J}=2.1 \mathrm{~Hz}, \mathrm{H}-1^{\prime}\right), 12.49(1 \mathrm{H}, \mathrm{s}, 5-\mathrm{OH})$. EI-MS: m/z $302\left\{[\mathrm{M}]^{+}, 100 \%\right\}$. The 
Afr. J. Trad. CAM (2006) 3 (4): 59 - 65

spectra data were in agreement with that of quercetin reported in the literature (Markham, 1982).

\section{Antioxidant activity}

Qualitative assay screening entailed spraying the TLC chromatograms of the partitioned fractions and the crude extract with $0.2 \% \mathrm{DPPH}$ in $\mathrm{MeOH}$. This revealed the antioxidant behaviour of the extracts. This was also repeated for the two compounds isolated.

Quantitative antioxidant activity was determined spectrophotometrically as described by Mensor et al., 2001, with some modifications. Briefly, the reactions were carried out in 96-well microtitre plates and each compound was tested at 100.0, 50.00, $25.00,12.50,6.25$ and $3.13 \mu \mathrm{M}$. Twenty micro liters of $0.3 \mathrm{mM}$ DPPH in methanol was added to $50 \mu \mathrm{L}$ of each concentration of sample tested and allowed to react at room temperature in the dark for thirty minute. Blank solutions were prepared with sample solution $(50 \mu \mathrm{L})$ and $20 \mu \mathrm{L}$ of methanol only while the negative control was DPPH solution, $20 \mu \mathrm{L}$ plus $50 \mu \mathrm{L}$ methanol. The decrease in absorbance was measured at 515 $\mathrm{nm}$ on a microplate reader. Values obtained were converted to percentage antioxidant activity (AA\%) using the formula:

$\mathrm{AA} \%=100-\left\{\left[\left(\mathrm{Abs}_{\text {sample }}-\mathrm{Abs}_{\mathrm{blank}}\right) \times 100\right] / \mathrm{Abs}_{\text {control }}\right\}$

$\left(\mathrm{Abs}_{\text {sample }}\right.$ is the absorbance of the sample, $\mathrm{Abs}_{\text {blank }}$ is the absorbance of the blank and $\mathrm{Abs}_{\text {control }}$ is the absorbance of the control). L-ascorbic acid (vitamin C) was used as a positive control (antioxidant agent).

The $\mathrm{EC}_{50}$ value, defined as the concentration of the sample leading to $50 \%$ reduction of the initial DPPH concentration, was calculated from the linear regression of plots of concentration of the test compounds $(\mu \mathrm{M})$ against the mean percentage of the antioxidant activity obtained from the three replicate assays.

\section{Statistical analysis}

The results were expressed as mean $\pm \mathrm{SEM}$ and the $\mathrm{EC}_{50}$ values obtained from the regression plots (Sigma Plots ${ }^{\mathrm{R}}$ 2001, SPSS Science) had a good coefficient of correlation, $\left(\mathrm{r}^{2} \geq 0.955\right)$.

\section{Result and Discussion}

Immediate bleaching of the purple DPPH colour by some constituents of EtOAc and $\mathrm{BuOH}$ fractions was observed on spraying TLC chromatograms of the solvent fractions of the crude extract with $0.2 \% \mathrm{DPPH}$ in $\mathrm{MeOH}$. The bleaching effect was also observed with the two compounds isolated.

The chemical structures of the two antioxidants: quercetin-3-O-rutinoside (1) and quercetin (2) were established by comparison of their spectral data with those reported in the literature (Harborne and Mabry, 1982; Markham 1982). 


\section{Afr. J. Trad. CAM (2006) 3 (4): 59 - 65}

These compounds were different in their antioxidant activity in quantitative assay, (Table 2). Compound $\mathbf{2}$ had higher antioxidant activity while Compound $\mathbf{1}$ had lower activity than L-ascorbic acid which was used as standard.

Conditions for effective radicals scavenging activity in flavonoids observed from structure activity relationship studies include the presence of catechols group (3'-OH and $4^{\prime}-\mathrm{OH}$ ) on ring $\mathrm{B}$, the $3-\mathrm{OH}$ group in combination with a $\mathrm{C} 2 \mathrm{C} 3$ double bond and keto group in position 4 (Gilbert et al., 2003, Harborne and Williams, 2000 and Saskia et al., 1996). These structural units fortify the antioxidant activity by increasing the stability of the flavonoids radical after donating phenolic hydrogen. The higher antioxidant activity of compound $\mathbf{2}$ compared to compound 1 could be due to the presence of free hydroxyl group in position 3 as both compounds have catechol group ( $3^{`}$ and $\left.4^{\prime} \mathrm{di}-\mathrm{OH}\right)$ on ring $\mathrm{B}$. It has been demonstrated that substitution of 3-OH reduces activity, (Op de Beck, 2003).

\section{Conclusion}

Many flavonoids have shown strong antioxidant properties (Harborne and Williams, 2000; Raj and Shalini, 1999). Quercetin-3-O-rutinoside (rutin) and quercetin have been established as strong antioxidant principles and had been used as standards in antioxidant experiments (Braca, et al., 2003; Mensor et al., 2003; Thabrew et al., 1998).

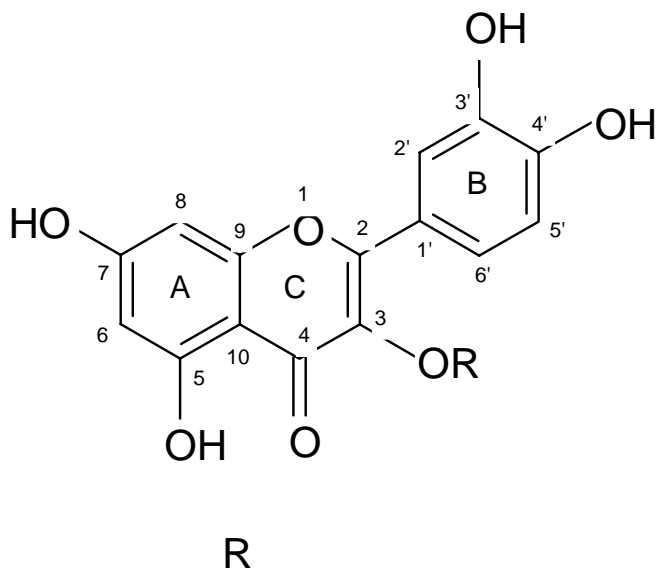

1. rutinosyl

2. $\mathrm{H}$

Figure 1: Antioxidants from B. monandra 
Afr. J. Trad. CAM (2006) 3 (4): 59 - 65

Table 1: Weights of the B. monandra leaves extracts

\begin{tabular}{|l|l|}
\hline Extract & Weight $(\mathrm{g})$ \\
\hline Methanol extract & 91.7 \\
\hline Hexane fraction & 5.3 \\
\hline Dichloromethane fraction & 4.1 \\
\hline Ethyl acetate fraction & 5.6 \\
\hline n-BuOH fraction & 29.2 \\
\hline
\end{tabular}

Table 2: Antioxidant potential of B. monandra constituents

\begin{tabular}{|l|l|}
\hline Sample & $\mathrm{EC}_{50} \pm \mathrm{SEM}(\mu \mathrm{M})$ \\
\hline Quercetin-3-O-rutinoside (1) & $16.11 \pm 0.581$ \\
\hline Quercetin (2) & $10.64 \pm 0.087$ \\
\hline L-ascorbic acid & $12.52 \pm 0.187$ \\
\hline
\end{tabular}

The presence of these compounds in abundance in the leaves extracts of $B$. monandra could provide rationale for the use of this plant in folk medicine.

Our results confirmed the earlier qualitative antioxidant analysis of B. monandra leaves extracts in which three major antioxidant compounds (flavonoids and steroid) were identified, (Argolo et al., 2004). We have now isolated, characterised and evaluated the antioxidant potential of the flavonoid constituents.

\section{Acknowledgements}

M.A. Aderogba is grateful to NRF South Africa, for the award of postdoctoral research fellowship and NAPRALERT for literature survey on the plant species.

\section{References}

1. Abo K.A. and Jimoh T.B. (2004). Anti-hyperglycaemic potential of stem bark of Bauhinia monandra (Kurz) in rats. Nig. J. Nat. Prod. and Med. 8: 45-51.

2. Argolo, A.C.C, Sant'Ana. A.E.G., Pletsch, M. and Coelho, L.C.B.B. (2004). Antioxidant activity of leaf extracts from Bauhinia monandra. Bioresour. Technol., 95: 229 - 233.

3. Braca, A., Fico, G., Morelli, I., De Simone, F., Tome, F. And De Tommasi N. (2003). Antioxidant and free radical scavenging activity of flavonol glycosides from different Aconitum species. J. Ethnopharmacol. 86: 63 - 67.

4. Binutu, O.A. (1998). Antibacterial activities of some leguminosae plants. Fitoterapia 69 (2): 187-188. 
5. Coelho, L.C.B.B. and Silva, M.B.R. (2000). Simple method to purify milligram quantities of the galactose-specific lectin from the leaves of Bauhinia monandra. Phytochem. Anal. 11 (5): 295-300.

6. Harborne, J.B. and Mabry, T.J. (1982). The Flavonoids: Advances in Research. Chapman and Hall Ltd. New York, USA, (Spectrum 62).

7. Holdsworth, D.K. (1990). Traditional medicinal plants of Rarotonga, Cook Islands. Part I. Int. J. Crude Drug Res. 28 (3): 209-218.

8. Markham, K.R. (1982). Techniques of Flavonoid Identification. Academic press INC., London, pp. 76, 84 and 90.

9. McCune, L.M. and Johns, T. (2002). Antioxidant activity in medicinal plants associated with the symptoms of diabetes mellitus used by the Indigenous people of the North American boreal forest. J. Ethnopharmacol. 82: 197 - 205.

10. Mensor, L. L., Menezes, F. S., Leitao, G.G., Reis, A.S., Santos, T.C., Coube, C.S. and Leitao, S.G. (2001). Screening of Brazilian Plant Extracts for Antioxidant Activity by the use of DPPH Free Radical Method, Phytother. Res. 15: 127 - 130 .

11. Op de Beck, P., Cartier, G., David, B., Dijoux-Franca, M. and Mariotte, A. (2003). Antioxidant flavonoids and phenolic acids from Leea guineense G. Don (Leeaceae). Phytother. Res. 17: 345 - 347.

12. Parr. A.J., Bowell, G.P. (2000). Phenols in the plant and in man. The potential of possible nutritional enhancement of the diet by modifying the phenol content or profile. J. Sci. Food Agric. 80: 985-1012.

13. Raj, K. J., Shalini, K., 1999. Flavonoids - a review of biological activities. India Drugs. 36: 668-676.

14. Schijlen, E.G.W.M., Ric de Vos, C.H., Van Tunen and Bovy, A.G. (2004). Modification of flavonoids biosynthesis in crop plants. Phytochemistry, 65: 2631 $-2648$.

15. Thabrew, M. I., Hughes, R. D. and McFarlane, I. G.1998. Antioxidant activity of Osbeckia aspera, Phytother. Res.12: $288-290$.

16. Tshibangu, J. N. Chifundera, K. Kaminsky, R., Wrigt, A. D. and Konig, G. M. (2002). Screening of African medicinal plants for antimicrobial and enzyme inhibitory activity, J. Ethnopharmacol., 80: $25-35$. 